\title{
A Comparative Study on Farmers Buying Pattern towards Chemical and Bio Fertilizers
}

\section{Sudhakar Dwivedi, Sabbey Sharma*, Jyoti Kachroo and Ashish Kumar Isher}

Sher-e-Kashmir University of Agricultural Sciences \& Technology of Jammu (JEK), India

*Corresponding author: sabbeysharma666@gmail.com

Received: $20-09-2020$

Revised: 18-11-2020

Accepted: $13-12-2020$

\section{ABSTRACT}

The study has been conducted to study the on various parameters which influences that buying behavior of farmers towards the purchase of fertilizers. The research was carried out on the basis of primary as well as secondary data. Two blocks, Ranbir Singh Pura and Satwari were selected purposively and from each block two villages were selected for the study. 25 farmers from each village were taken randomly which constituted the total sample size of 100 farmers. The research was descriptive type and convenience sampling tool was used to select the farmers. The study revealed that the highest number of the farmers i.e. 46 per cent use Urea, DAP and MOP. The highest number of the respondents i.e. 47 per cent said that they use the fertilizers to get the quantity and production enhancement. The study revealed that the majority of the respondents i.e. (78 per cent) said that they take buying decision of fertilizers by themselves and 37 per cent said that the price factor majorly influence their buying behavior towards fertilizers.

Keywords: Perception, Behaviour, Fertilizer, Bio-fertilizer

Agricultural sector has been the foundation of Indian economy its growth and development across the regions and crops is of vital significance in ensuring food security, accomplishing self-reliance, supplying raw materials to industries and generating effective demand in the economy through linkages. Though, in spite of intensive efforts by the government at the centre through planned outlay, there has been little structural transformation of the Indian agricultural sector. Agriculture is the main source of living for about 58 per cent of India's population. The gross value added (GVA) by agriculture, forestry and fishing was estimated at ₹ 19.48 lakh crore (US\$ 276.37 billion) in financial year 2019-20. The growth in GVA in agriculture and allied sectors stood at 4 per cent in 2019-20 (Source: ibef.org)

The chemical fertilizers are characterized as fertilizers consisting of inorganic chemicals which could be produced artificially. Some people call chemical fertilizers as Straight fertilizers. They provide only one primary plant nutrient, namely nitrogen or phosphorus or potassium. E.g.: Urea, ammonium sulphate, potassium chloride and potassium sulphate. Farmers occasionally mix-up few type of chemical fertilizers to make a desired NPK proportion before application. It is relatively cost-saving method to manure crops but it needs a proper understanding about requirement of nutrients to the soil. The chemical fertilizer are those fertilizer which are made up by the process of chemical synthesis or chemical reactions, whose ingredients

\footnotetext{
How to cite this article: Dwivedi, S., Sharma, S., Kachroo, J. and Isher, A.K. (2020). A Comparative Study on Farmers Buying Pattern towards Chemical and Bio Fertilizers. Agro Economist - An International Journal, 7(2): 159-162.

Source of Support: None; Conflict of Interest: None
} 
have certain amount of nutrients for the plants, such as phosphorus, potassium, copper, zinc nitrogen, magnesium, calcium, sulphur, boron, , manganese, iron, molybdenum, etc. including simple-substances and compound fertilizers.

The bio-fertilizers are biologically active products or microbial inoculants consisting of bacteria, algae, fungi or biological compound which may be advantageous to soil and plants. These fertilizers are not detrimental to the environment contrasting the chemical fertilizers. It is generated from the residue of animals, plants alongside with the microbial mixtures. Microorganisms are used to enhance nutrient level uptake by the plants and restore biodiversity of the soil. Bio-fertilizers allow the plants develop in a healthy environment where it is doing not cause the pollution of any sort. Biofertilizer often refers to microbial fertilizers that use active microorganisms to enhance the nutrient concentration or their availability in soils, increase absorption, or protect the roots. It is generally called microbial fertilizer or microbial inoculants, because of the most frequent utilization of microorganisms.

\section{MATERIALS AND METHODS}

The study adopted both primary as well as secondary data methods for collection of data from the sample area. For this study Jammu district has been taken purposively and for the collection of the relevant information, the survey was conducted among the farmers of two blocks namely Ranbir Singh Pura and Satwari was selected from the Jammu district as majority of farmers are progressive and using chemical as well as bio-fertilizers and 25 farmers (respondents) from each village were selected randomly to constitute a sample size of 100 respondents. The data has been collected through the market survey using questionnaires as the measurement tool. The study was based on descriptive type.

\section{RESULTS AND DISCUSSION}

For fulfilling the objective of the research, 100 respondents from Jammu were surveyed. Out of 100 respondents, 97 per cent farmers were male followed by 3 per cent respondents were female. The farmers buying behavior pattern towards chemical and bio fertilizers it was very necessary to know the land holdings of farmers. Table 1 revealed that Out of 100 respondents, 71 per cent respondents were marginal farmers having land possession of $1-2.5$ acres, 16 per cent respondents were small farmers having land possession of 2.5 - 5 acres, 11 per cent respondents were medium farmers having land possession of 5 - 10 acres, followed by 2 respondents were large farmers having land possession of more than acres.

Table 1: Gender and Land holding of the Farmers

\begin{tabular}{ll}
\hline Gender of the Respondents & Percentage \\
\hline Male & 97.00 \\
Female & 3.00 \\
Total & 100.00 \\
Land holdings of the Farmer & Percentage \\
Marginal farmers (1 - 2.5 Acres) & 71.00 \\
Small farmers (2.5 - 5 Acres) & 16.00 \\
Medium farmers ( 5 - 10 Acres) & 11.00 \\
Large farmers (More than 10 Acres) & 2.00 \\
\hline Total & $\mathbf{1 0 0 . 0 0}$ \\
\hline
\end{tabular}

The Table 2 revealed that the mostly preferred fertilizer by the respondents. Out of 100 respondents, the 17 per cent farmers said that they mostly use Urea, DAP, MOP and Bio-Fertilizers, 46 per cent farmers said that they mostly use Urea, DAP and MOP, 21 per cent farmers said that they mostly use Urea and DAP, 9 per cent farmers said that they mostly use Urea and MOP and only 7 per cent farmers said that they mostly use Urea and Bio-Fertilizers.

Table 2: Most preferred fertilizer by the farmer

\begin{tabular}{ll}
\hline Options & Percentage \\
\hline Urea, DAP, MOP and Bio-Fertilizers & 17.00 \\
Urea, DAP, MOP & 46.00 \\
Urea and DAP & 21.00 \\
Urea and MOP & 9.00 \\
Urea and Bio-Fertilizers & 7.00 \\
\hline Total & $\mathbf{1 0 0 . 0 0}$ \\
\hline
\end{tabular}

For studying the Market of fertilizers, it was essential to identify the various reasons influencing farmers to buy fertilizers. During the survey the response was collected against the three factors i.e., quantity and production enhancement, Quality produce, Soil fertility. From the data, it can be analyzed 
that majority of the farmers i.e. 47 per cent use the fertilizers to get the quantity and production enhancement whereas 28 per cent farmers said that they use the fertilizers to get the quality produce. Only 25 per cent farmers use the fertilizers to get the soil fertility.

Table 3: Reason for the use of fertilizers

\begin{tabular}{ll}
\hline Reasons for the use of fertilizers & Percentage \\
\hline Quantity and production enhancement & 47.00 \\
Quality produce & 28.00 \\
Soil fertility & 25.00 \\
\hline Total & $\mathbf{1 0 0 . 0 0}$ \\
\hline
\end{tabular}

Table 4 represents the purchase of fertilizers by the farmers. The collected data revealed that all the farmers were accessing the local market to purchase the fertilizers and no farmer purchase the fertilizers from government agencies and others.

Table 4: Purchase of fertilizers by the Farmer

\begin{tabular}{ll}
\hline Options & Percentage \\
\hline Local market & 100.00 \\
\hline Total & $\mathbf{1 0 0 . 0 0}$ \\
\hline
\end{tabular}

The table 5 depicted the influence over buying decision regarding the purchase of fertilizers. After analyzing the data it was found that 78 per cent farmers said that they take buying decision of fertilizers by themselves, 19 per cent farmers said that their buying decision got influenced by the friends, whereas only 3 per cent respondents said that their buying decision is influenced by the advertisements.

Table 5: Influence over buying decision regarding the purchase of fertilizers

\begin{tabular}{ll}
\hline Influence over buying decision & Percentage \\
\hline Self-decision & 78.00 \\
Friends \& Relatives & 19.00 \\
Advertisement & 3.00 \\
\hline Total & $\mathbf{1 0 0 . 0 0}$ \\
\hline
\end{tabular}

For studying the buying behavior of fertilizers, it was essential to identify the impact of various factors on the buying behavior of the farmer. During the survey the response was collected against the five factors (i.e., Price, Quality, Easy Availability, Packaging and Certification). From the data, it was analyzed that out of 100 respondents, 37 per cent farmers said that price influences their buying behavior, 29 per cent farmers said that quality influences their buying behavior and 12 per cent farmers said that easy availability influences their buying behavior. As far as certification of the product was concerned 19 per cent farmers said that the certification influences their buying behavior. Only 3 per cent farmers said that packaging influences their buying behavior.

Table 6: Factors influencing the buying behavior of the Farmer

\begin{tabular}{ll}
\hline Options & Percentage \\
\hline Price & 37.00 \\
Quality & 29.00 \\
Easy Availability & 12.00 \\
Packaging & 3.00 \\
Certification & 19.00 \\
\hline Total & $\mathbf{1 0 0 . 0 0}$ \\
\hline
\end{tabular}

Now a days the best way to promote product is word of mouth, it is achieved by providing best quality. From the above table it can be concluded that the Out of 100 respondents, 32 per cent respondents said that retail traders influence their buying behavior, 7 per cent respondents said that on farm demonstration influence their buying behavior, 29 per cent respondents said that farmers meeting influence their buying behavior, 16 per cent respondents said that through participation in fairs they make their buying decision, 1 per cent respondents said that posters influence their buying behavior, 6 per cent respondents said that radio as a source of information, influence their buying behavior and only 9 per cent respondents said that local papers influence their buying behavior.

Table 7: Influence of promotional activities on farmers buying behavior

\begin{tabular}{ll}
\hline Options & Percentage \\
\hline Retail traders influence & 32.00 \\
On farm demonstration & 7.00 \\
Farmer meetings & 29.00 \\
Through participation in fairs & 16.00 \\
Posters & 1.00 \\
Radio & 6.00 \\
Local papers & 9.00 \\
\hline Total & $\mathbf{1 0 0 . 0 0}$ \\
\hline
\end{tabular}




\section{CONCLUSION}

From the study it was concluded that the majority of the respondents i.e. (100 per cent) said that they use the fertilizers. The highest number of the respondents i.e. (46 per cent) said that they mostly use Urea, DAP and MOP, followed by ( 21 per cent) said that they mostly use Urea and DAP. The highest number of the respondents i.e. (47 per cent) said that they use the fertilizers to get the quantity and production enhancement, followed by the 28 respondents i.e. (28 per cent) said that they use the fertilizers to get the quantity produce. The majority of the respondents (100 per cent) said that they purchase the fertilizers from local markets. The study revealed that the majority of the respondents i.e. 78 per cent said that they take buying decision of fertilizers by themselves. The majority of the respondents i.e. (38 per cent) said that they have a highly satisfying overall experience of using fertilizers. The highest number of the respondents i.e. (37 per cent) said that price influences their buying behavior towards fertilizers. The highest number of the respondents i.e. (32 per cent) said that retail traders influence their buying behavior towards the fertilizers.

\section{REFERENCES}

Adrian, A.M., Norwood, S.H. and Mask, P.L. 2005. Producers' perceptions and attitudes toward precision agriculture technologies. Computers and Electronics in Agriculture, 48(3): 256-271.

Aaker, D.A. and Joachimsthaler, E. 2000. Brand Leadership, The Free Press, New York 2(3): 25-33.
Ajewole, O.C. 2010. Farmer's response to adoption of commercially available organic fertilizers in Oyo state, Nigeria. African Journal of Agricultural Research, 5(18): 2497-2503.

Anonymous, 2020. Agriculture in India: Information about Indian Agriculture and its Importance. Ibef.org. Accessed on 16-9-2020.

Anonymous, 2020. Indian fertilizer market: Industry trends, share, size, growth, opportunity and forecast 2020-2025. Imarcgroup.com. Accessed on 16-9-2020.

Armstrong, G. 2016. Principles of Marketing, 3(2): 36-41. Prentice Hall, London.

Armstrong. 2016. Farmers' behavior and preferences in purchasing fertilizer, 6(8): 65-71. Mc Graw-Hill, New York.

Bagal, Y.S., 2018. Trends and Patterns in Fertilizer Consumption International Journal of Current Microbiology and Applied Sciences, 7(4): 480-487.

Boateng, K. 2000. Effects of application of poultry manure on growth, yield and economic returns of Okra growth in the forest zones of Ghana. Ghana Journal of Horticulture, 1(3): 9-13.

Chaudhuri, A. 2012. Emotion and Reason in Consumer Behaviour, 4(9): 54-82, Elsevier New York.

Corinne, E. Alexander, Christine, A., Wilson, and Daniel, H. and Foley. 2005. Agricultural Input Market Segments: Who Is Buying What. Journal of Agribusiness, 23(2): 45-49.

Dim, Y.E. and Morant, R.T.2003. Perceived value of Biofertilizers by farmers. American Journal of Agricultural Economics, 6(4): 11-16.

Du Plessis, F., Rousseau, D., Boshof, C., Ehlers, L., Engelbrecht, M., Joubert, R. and Sanders, S. 2007. Buyer behaviour. Understanding Consumer Psychology and Marketing, 4(67): 196-205. Cape Town: Oxford. 